\title{
Portuguese or Portuñol? Language contact in Misiones, Argentina
}

\author{
John M. Lipski* \\ The Pennsylvania State University
}

In the extreme northeastern Argentine province of Misiones, vernacular Portuguese is the primary language of many rural communities, in bilingual contact with Spanish. The present study examines data from Misiones Portuguese and Spanish for evidence of morphosyntactic convergence in the absence of formal schooling in either language or sociolinguistic pressures to produce canonical varieties. Data from a corpus of vernacular Misiones Portuguese and the results of a speeded translation task reveal that even in this sociolinguistically permissive environment bilingual speakers maintain distinct morphosyntactic systems for Portuguese and Spanish (exemplified by nominal plural marking and first-person plural verbal inflection). The data also suggest that bilingual contact alone does not yield the degree of convergence required for the hybrid Portuguese-Spanish morphosyntaxis that has been reported, for example, in northern Uruguay.

\section{Introduction}

Sustained contact between two languages in unofficial settings, such as border or immigrant communities or in multilingual trade environments, frequently produces linguistic contact phenomena that are popularly referred to by words suggesting mixed parentage. Such curiosities as Taglish, Hinglish, Spanglish, Franglais, Guarañol, Quechuañol, etc. are not generally construed as stable mixed languages but rather serve as cover terms for variable crossover phenomena in spontaneous speech, often produced by individuals with unequal bilingual competence. Typological differences between the languages may effectively limit contact phenomena to lexical borrowings and calques, which when frequent enough can give the impression of a new, hybrid language, but which in reality do not affect the fundamental structures of either language. In the case of typologically congruent languages in contact, the possibilities for hybrid morphosyntactic configurations are enhanced, with the potential for hybridization further augmented by lexical cognates (the "homophonous diamorphs" of Muysken, 2000:123).

One contender for a true hybrid language is embodied in the popular designation Portuñol (in Spanish)/ Portunhol (in Portuguese). Prior to the $13^{\text {th }}$ century two separate languages had not been consolidated, although regional features could already be observed; now Spanish and Portuguese-spoken in separate nations and enjoying long literary traditions-are invariably classified as distinct languages, although many of the differences are quite systematic, and a high

*Address for correspondence: John M. Lipski, Department of Spanish, Italian and Portuguese, 231 Burrowes Building, The Pennsylvania State University, University Park, PA 16802, U. S. A. 1-814-865-6583 (telephone), 1-814-863-7944 (fax), jlipski@psu.edu degree of mutual intelligibility exists between most varieties. Currently portuñol/portunhol is applied to two very distinct situations (e.g., Lipski, 2006; Marcos Marín 2001). Frequently portuñol/portunhol has a developmental meaning, referring to $\mathrm{L}_{1}$-induced interference that occurs when speakers of one of the two highly cognate languages attempt to speak the other but are unable to suppress interference from the native language. More to the point, as regards the formation of stable contact varieties, this term has also been applied to bilingual configurations in nominally Spanishspeaking communities bordering on Brazil (e.g., Amorim, 2007; Sturza, 2004), with the implicit or explicit suggestion that a "new" language may have emerged. In addition to the many border regions where native Spanish speakers learn Portuguese as a second language to speak to Brazilians, there are two dialect zones where vernacular Portuguese-and also possible PortugueseSpanish hybrid varieties-are spoken natively, and where stable language-contact phenomena can be observed. The first is the widely studied northern Uruguayan region, where a variety known to linguists as Fronterizo "border speech" or dialectos portugueses del Uruguay (Uruguyan dialects of Portuguese), and by the speakers themselves as portuñol, is widely used. Another important dialect cluster, as yet little studied and with unique sociolinguistic features not found in northern Uruguay, is located in the extreme northeastern Argentine province of Misiones, where Portuguese is spoken as a first language in several rural communities and small towns. It is the latter dialect region that constitutes the central focus of the present study. The lack of formal schooling in Portuguese or Spanish combined with the virtual absence of sociolinguistic pressures to speak one language or the other-or to approximate canonical varieties of either language-provide an 
environment in which to observe the possible modulating effects of typological and lexical similarity on language convergence.

The purpose of the present study is to examine key elements characteristic of the vernacular Portuguese in eastern Misiones province, Argentina, and to determine-both observationally and by means of an interactive task-the extent to which Spanish and Portuguese systems remain separate in an environment virtually free of sociolinguistic pressures. The data also serve to probe for grammatical restructuring of vernacular Misiones Portuguese away from canonical Brazilian configurations. The variables to be examined include depleted plural marking in noun phrases, realization of the first-person plural verbal suffix, and invariant first-person plural imperfective verb forms, as well as bilingual speakers' reactions to nominally mixed Portuguese-Spanish utterances. It is hypothesized that in this sociolinguistic "free-for-all" environment the possibilities for morphosyntactic convergence are at their greatest, as is the potential for the emergence of a stable hybrid portuñol/portunhol. If under these circumstances the vernacular Spanish and Portuguese configurations remain differentiated, it can be surmised that contact-induced convergence alone is not sufficient to account for putative Spanish-Portuguese hybrid phenomena documented elsewhere, e.g., in northern Uruguay.

\section{L1 Portuguese in Misiones, Argentina}

\subsection{Portuguese as L2 just beyond the borders of Brazil}

Brazil, the largest nation in South America, shares a common border with every Spanish-speaking country in the continent except for Chile and Ecuador, and in every Spanish-speaking nation bordering on Brazil there are one or more communities located on the border, nearly always paired off with a corresponding community on the Brazilian side. The Brazilian linguist Sturza (2005:50), acknowledging the paucity of information on border varieties of Portuguese, observed that "A língua portuguesa além das fronteiras brasileiras é uma outra língua" [the Portuguese language beyond the Brazilian borders is another language]. These border communities are far from the respective national capitals in regions that historically have been slow to be populated and were beyond the reach of national television and radio stations. To this day Brazilian television is the predominant media presence nearly everywhere along the Brazilian border with Spanishspeaking nations (although small local Spanishlanguage radio stations abound), and only recently has satellite television enabled access to national and international Spanish-language programming. At the same time, the burgeoning economy of Brazil has resulted in favorable currency exchange values for Brazilians, resulting in the presence of businesses and duty-free zones in many of these communities. Perhaps as a result of these factors Brazilians in border regions usually do not use Spanish, while residents of border communities in Spanish-speaking nations have considerable passive knowledge of Portuguese and use this language (with varying degrees of proficiency) when speaking with Brazilians and under some circumstances also with one another (e.g., Lipski, 2011a, 2011b; Sturza, 1994; Sturza \& Fernandes, 2009). ${ }^{1}$

\subsection{Portuguese as L1 in Misiones, Argentina}

The province of Misiones, in the extreme northeast of Argentina, is a narrow peninsula bordered by Paraguay to the west and Brazil to the east. Misiones officially became a territory of Argentina in 1881, but did not gain provincial status until 1953. Between 1883 and 1927 Argentina recruited European settlers to this sparsely populated region, mostly from the Ukraine and Poland. After World War I many German settlers also arrived in Misiones, attracted by German-owned business in South America. A considerable Swedish immigration also occurred during the same period. Even more immigrants-many arriving without authorization-came from neighboring Brazil, which is separated from most of Misiones by the narrow Uruguay River and in a few places only by small creeks; in one area there is a land border with no natural demarcation. Throughout the eastern portion of the province Portuguese continues to be the dominant language in all rural regions and in some urban centers as well. Most Misiones Portuguese speakers work in agriculture, on small farms producing tea, yerba mate, tobacco, and aromatic plants such as citronella and mint, from which the essential oils are extracted in distilleries. Others have established sawmills and carpentry shops, exploiting the province's rich forest resources.

Amable (1975:24-25), writing in the 1960's, characterized the use of Portuguese in Misiones as "un verdadero dialecto dentro del habla regional" [a true dialect within regional speech] and noted that in the eastern portion of the province only Portuguese was spoken until recently, and that bilingualism still prevailed in this area, although he predicted that "habrán de pasar dos o tres generaciones más (entre 30 y 45 años de tiempo) para que se plasme el lenguaje regional, sin bilingüismo" [two or three generations-30 to 45 years-will have to pass before regional speech is no longer bilingual]. In fact even more time has passed since the writing of these remarks, and Portuguese is still tenaciously maintained throughout eastern Misiones.

Portuguese is spoken as a home language in rural areas of Misiones from Puerto Iguazú and Comandante 
Andresito in the north all along the eastern corridor near the Uruguay River as far south as San Javier. The greatest concentration of speakers is found between the river town of $\mathrm{El}$ Soberbio and the village of Colonia Aurora with its rural dependencies Colonia Alicia and Puerto Londero. El Soberbio stands out among all the communities in Misiones in that vernacular Portuguese is the principal language of the entire community, spoken in businesses, government offices, and in formal and informal exchanges. The previous mayor hosted a daily program in "portuñol" on the local radio station, and signs in Portuguese are found throughout the town. In the surrounding agricultural zones Portuguese is spoken nearly exclusively. Also located near the Uruguay River is Santa Rita, where Portuguese can also be heard in the small urban area as well as in the surrounding rural zones. A nucleus of Portuguese speakers relocated from Colonia Aurora/Colonia Alicia is found in the north-central town of Pozo Azul, whose surrounding areas are not populated by Portuguese speakers. Map 1 shows the locations of the principal Portuguese-speaking areas.

\section{By way of Comparison: Vernacular Portuguese in Northern uruguay}

The study of Portuguese-Spanish contacts outside of the Brazilian border was initiated with research in northern Uruguay, beginning with Rona $(1960,1969)$ and brought to the attention of linguists outside of South America by Hensey (1972). Both referred to the local vernacular as fronterizo (fronteiriço in Portuguese), meaning roughly "on the border." Although these works describe what is essentially a highly vernacularized Portuguese with Spanish borrowings, the studies are couched in terms of a "third" language, a PortugueseSpanish hybrid that freely combines elements of both languages in fashions that go beyond the usual contact-induced borrowing. Elizaincín (1979) later clarified the linguistic situation in northern Uruguay as "Uruguayan Portuguese dialects" (dialectos portugueses del Uruguay), but among the speakers themselves the local vernacular is referred to neither as Portuguese nor Fronterizo but rather as portuñol (and outsiders have applied the derogatory term rompe-idioma 'languagebreaker'). Popularizing accounts of "Fronterizo," including fanciful versions of the Lord's Prayer and other prayers (www.christusrex.org/www1/pater/ JPN-fronterizo.html) are not always representative of naturalistic speech and tend to emphasize and even exaggerate Portuguese-Spanish admixtures. The singersong writer Chito de Mello, native of Rivera, Uruguay, has recorded many songs in "Portuñol," some of which even contain "lessons" in the proper use of this vernacular (www.chitodemello.blogspot.com).
Additional studies of northern Uruguayan Portuguese include Behares (2005), Elizaincín (1973, 1976, 1992), Elizaincín, Behares, and Barrios (1987), Carvalho (2003a, 2003b, 2004a, 2004b, 2006a, 2006b), Douglas (2004), Hensey (1982a, 1982b), Kaufmann (2009), and Waltermire (2006).

In the past, northern Uruguay was disputed between the newly independent nations of Brazil and Uruguay, and was settled by Brazilians for a considerable time. The reasons for the formation of fronterizo dialects, rather than simple bilingualism with code switching and a light overlay of borrowings (as found, e.g., in the Spanish of the southwestern United States) are rooted in a complex set of socio-historical facts, in which the rural residents of an isolated and marginalized zone were pulled linguistically in two directions, but where neither pull was strong enough to completely suppress the other language.

\section{The Sociolinguistic Environment of Misiones Portuguese}

The Portuguese spoken in Misiones bears the mark of rural vernacular Brazilian Portuguese of the neighboring states, and has little resemblance to urban standardized Portuguese. Basic descriptions can be found in Lipski (2011b, 2015) and Maia (2004); Misiones Portuguese is also mentioned by Daviña (2003), Sturza (1994). Despite the fact that most residents of the chacras (small farms) of eastern Misiones listen to Brazilian Portuguese media, there is no attempt to emulate prestigious Brazilian varieties, unlike the situation in northern Uruguay (Carvalho, $2004 a){ }^{2}$ In most of these communities at least some Portuguese is also spoken as a second language by individuals involved in commerce with Brazil or with visiting Brazilians, but only in a few communities is L2 Portuguese usage extensive (e.g., in Bernardo de Irigoyen, which has an open land border with Brazil).

As in northern Uruguay, the massive presence of Spanish in Misiones arrived with immigrants from more populated regions of the country. The principal difference is that in Misiones the use of Portuguese never provoked the harsh rejection found in northern Uruguay. Misioneros' tolerance of "Portuñol" is much greater than non-Portuguese-speaking Uruguayans' views towards fronterizo dialects. Although most of the schools in the Portuguese-speaking communities in Misiones do not offer classes in Portuguese, and despite the fact that children from Portuguese-speaking households frequently experience language difficulties in the first years of school, there has never been a campaign to eradicate Portuguese, or to label rural vernacular speech with terms like rompe-idioma 'language-breaker' as used in Uruguay. With the exception of towns such as El Soberbio and Santa Rita, 


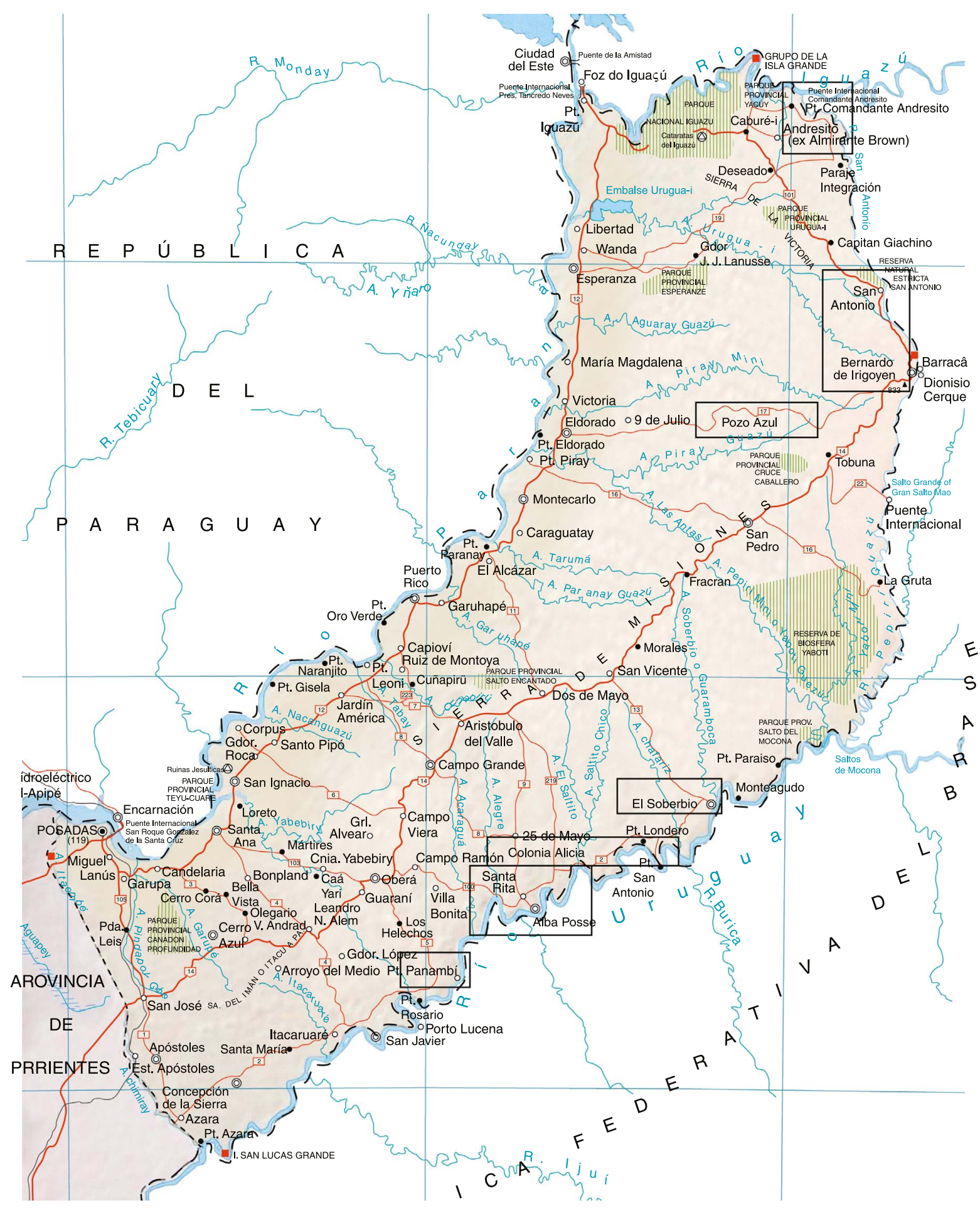

Map 1. Portuguese-speaking communities where data were collected

Portuguese speakers in Misiones are generally rural residents, but speaking Portuguese is not publicly criticized or explicitly correlated with working-class or rustic speech. Misioneros' views toward Portuguese often involve gently humorous acknowledgement of "portuñol." ${ }^{3}$
In Misiones, the fact that Portuguese is most frequently spoken in rural regions contributes to its tenacity. Unlike in urban areas, where interaction with Spanish speakers inevitably results in language mixing and ultimately in the displacement of Portuguese by Spanish, on the small farms of Misiones residents spend 
most days speaking to one another only in Portuguese. This fact, combined with the relatively little sociolinguistic stigmatization of Portuguese/Portuñol, results in Misiones Portuguese having comparatively fewer Spanish incursions than Uruguayan fronterizo.

\section{In Search of Misiones Portuguese/Portuñol: Key Variables}

Given the frequent use of the term Portuñol in Misiones, one can pose the question of whether two separate linguistic systems continue to exist despite the extensive Portuguese-Spanish interface, as opposed to a single merged system incorporating lexical items originating in two languages. In view of the highly cognate nature of Spanish and Portuguese, including morphosyntax, lexicon, and many phonetic patterns, the search for answers must focus on specific configurations where the two languages differ significantly. In the case of vernacular Brazilian Portuguese as spoken along most of the Brazilian border and especially in Misiones province, at least three possible loci of divergence from local Spanish varieties can be identified. Two involve the interface between morphology and phonology: reduced plural agreement in noun phrases and the realization of first-person plural verb endings as $-m o$ instead of the canonical -mos as well as the variant -emo instead of -amos for first-conjugation (-ar) verbs. Another feature is the replacement of first-person plural verb forms with invariant forms derived from the thirdperson singular.

The variability of plural marking, /-s/-deletion in/-mos / verb forms, and use of invariant third-person singular verb forms have generally been regarded as systematically conditioned variable rules in Brazilian Portuguese, influenced by a variety of contextual, pragmatic, and sociolinguistic factors. In all instances it is implicitly assumed that speakers are aware of the full variants even when not producing them, given the presence of these variants in the speech communities and their prominence in mass media and the educational system. In the case of Misiones, Portuguese is not taught in the schools, and the speech communities do not contain a sociolinguistic cross-section that includes speakers of more educated Portuguese varieties. At the same time most Portuguese speakers in Misiones consistently hear educated Brazilian Portuguese in radio and television programs, so it is unlikely that the differences between educated Brazilian and vernacular Misiones Portuguese pass entirely unnoticed. In the author's many informal conversations, Misiones speakers have acknowledged that they do not emulate the Portuguese varieties heard on Brazilian broadcasts, while exhibiting no reluctance in speaking the local vernacular.

\section{A Corpus of Misiones Vernacular Portuguese (Portunhol?)}

To date there have been no quantitative or variationist studies of Misiones vernacular Portuguese that would situate this variety within a larger circum-Brazilian context. In order to set the stage for an inquiry into possible contact-induced phenomena in the Misiones Portuguese-Spanish interface, a corpus was extracted from the author's recorded sociolinguistic interviews, spanning the period 2008-2014. The format was free conversation in both Spanish and Portuguese on a range of topics that included agricultural practices, community events, and personal histories. All interviews were conducted by the author. The data represent a total of forty-eight Portuguese-Spanish bilinguals (ages 18 to mid-50's), all natives of the Misiones communities in which they were interviewed and none with formal training in Portuguese or residence or extended visits in Brazil. Data were obtained from the following towns and surrounding rural areas: Comandante Andresito, San Antonio, Bernardo de Irigoyen, El Soberbio, Barrerinho, Colonia Alicia, Santa Rita, Alba Posse, 25 de Mayo, Pozo Azul, and Panambí. For each speaker a fifteen-minute continuous segment was randomly selected and all instances of plural noun phrases and first-person plural verb forms were transcribed and analyzed.

\section{Depleted Plural Marking in Vernacular Brazilian and Misiones Portuguese}

A characteristic trait of vernacular Brazilian Portuguese is depleted plural marking, placing plural /-s/ only on the first element of plural noun phrases, typically a determiner: os livro[s] 'the books,' as pessoa[s] 'the people.' This depleted plural marking is even more salient in the case of consonant-final nouns and adjectives, which instead of taking the usual Brazilian plural allomorph -es often remain invariant: as mulher[es] velha[s] 'the old women.' Within Brazil the rate of depleted plural marking appears to be decreasing in recent generations, due to greater access to public education as well as perhaps increased penetration of communications media. For example in Rio de Janeiro in the 1970s the rate of omission of plural /-s/ in the second position of noun phrases was $72 \%$ whereas a cross-section including more educated speakers from São Paulo collected around 2010 showed a rate of only around 14\% (Guy, 2014:452-453).

In monolingual varieties of Spanish some analyses have claimed similar processes of depleted plural formation, but only in dialects in which coda /s/ is frequently deleted as part of a generalized phonological process (e.g., Ferreira, 2001; Guy, 1981; Poplack, 1980, 
1981). The existence of a phonetically-motivated process of /s/-effacement that includes plural /-s/ in Spanish adds a confounding factor since the root cause (s) of the absence of phonetically realized /s / in a plural noun phrase may be morphological, phonological, or a combination of both. On the other hand true stripped plurals (including invariant consonant-final plurals) are relatively uncommon in monolingual Spanish varieties, e.g. southern Spain, where widespread loss of wordfinal consonants often leads to phonological restructuring in vernacular speech, resulting in the loss of canonical plural endings: árbo < árbol, árboles 'tree(s)' (Carrasco Cantos, 1981:99). ${ }^{4}$ Monolingual Spanish dialects in which coda /s/ is realized as [s] do not systematically exhibit depleted plural marking, except for two small Afro-Hispanic speech communities, one in Ecuador and the other in Bolivia (Lipski, 2010); these same dialects also exhibit stripped/invariant consonant-final plurals. Stripped plurals also occasionally occur in contact varieties of Spanish in the speech of nonfluent bilinguals (e.g., Lipski, 2008b, 2009b for Paraguay).

In northern Uruguay, Carvalho (2006b:162-163) has demonstrated some convergence between the pluralmarking of vernacular Uruguayan Portuguese and the local variety of Spanish, with the latter showing signs of morphologically-conditioned depleted plural marking, noting that:

the borrowing of this Portuguese rule into Spanish does not entail a radical change in the recipient language, since it coincides with its internal tendency to lose syllable-final /s/, which, in many cases, results in loss of plural information. Thus, this borrowed feature is incorporated relatively easily into Spanish, due to a high degree of integration that results from a high level of congruency of grammatical and variational patterns. In this case, the application of a Portuguese rule pushes toward the loss of nominal agreement already common in Spanish, primarily caused by the loss of the /s / phoneme.

Complete plural stripping in Spanish does not normally occur with consonant-final nouns and adjectives, but a few instances are found in the Spanish of the border city of Rivera, Uruguay.

The intense Spanish-Portuguese contacts in Misiones provide a propitious environment for the convergence of plural-marking systems, given the virtual absence of sociolinguistic or prescriptive pressures on either language. The demonstrated existence of convergence would lend credence to the notion of "Portuñol" as an emergent hybrid contact vernacular rather than a clear demarcation between local varieties of Spanish and Portuguese. All Spanish dialects of Misiones are characterized by high rates of deletion of word-final /s/ (e.g., Sanicky, 1981), which makes it difficult to probe for Portuguese-influenced morphological reduction of plural marking. All of the Portuguese speakers in Misiones also speak Spanish, with varying degrees of fluency. Portuguese-speaking children come into contact with more canonical varieties of Spanish in school settings, where they are exposed to Spanish plural marking with /-s / on all NP elements, albeit in the form of aspirated [h] rather than sibilant [s]. Away from school settings, however, both children and adults most frequently encounter Spanish spoken with high rates of elision of coda /s/. Depleted plural marking such as found in vernacular Brazilian Portuguese is not characteristic of Misionero Spanish, although given the high rates of aspiration and deletion of syllable- and wordfinal /s / in all Misiones Spanish dialects it is not always possible to determine whether a plural noun phrase pronounced without final [s] (e.g., las casas [lah.ká.sa] 'the houses') is the result of a morphological process of depleted plural marking or a phonological process of weakening word-final /s/ to the point of total effacement, especially in phrase-final contexts or in rapid speech. Invariant consonant-final plurals such as *las mujer for las mujeres 'the women' almost never occur (only occasionally in the Spanish of the most Portuguese-dominant speakers, e.g., recent Brazilian immigrants), which suggests indirectly that loss of /-s / in Spanish plural noun phrases is a variable phonological phenomenon rather than a morphologicallyinduced reduction process.

Vernacular Misiones Portuguese exhibits high rates of depleted plural marking, including invariant consonant-final nouns and adjectives; the results from the aforementioned corpus are shown in Table 1.

Variable plural marking in vernacular Brazilian Portuguese has been subjected to variationist analyses that demonstrate the effects of priming based on linearbased parallelism: once more than one plural /-s/ is

Table 1. Plural agreement in Misiones Portuguese plural NPS

\begin{tabular}{|c|c|}
\hline Category & $\begin{array}{c}\% \text { fully agreeing plural } \\
\text { marking in /-s/ }\end{array}$ \\
\hline vowel-final $(\mathrm{N}=1274)$ & $5.5 \%$ \\
\hline consonant-final $(\mathrm{N}=129)$ & $6.2 \%$ \\
\hline diphthong-final - $\tilde{a} o(\mathrm{~N}=58)$ & $1.7 \%$ \\
\hline \multicolumn{2}{|l|}{ Preceding string } \\
\hline$S_{2}(\mathrm{~N}=955)$ & $5.2 \%$ \\
\hline $\mathrm{N}_{\ldots}(\mathrm{N}=384)$ & $3.6 \%$ \\
\hline$S S \quad(N=20)$ & $10 \%$ \\
\hline $\mathrm{S}{ }_{\ldots} \ldots(\mathrm{N}=50)$ & $2 \%$ \\
\hline $\mathrm{SN}_{-}(\mathrm{N}=25)$ & $0 \%$ \\
\hline$\varnothing S_{\perp}(\mathrm{N}=3)$ & $0 \%$ \\
\hline $\operatorname{ALL}(\mathrm{N}=1461)$ & $5.4 \%$ \\
\hline
\end{tabular}


realized-for whatever reason-this increases the likelihood of subsequent plural markers, while the same is true for missing plural markers. These studies have demonstrated linear parallel effects on the marking of plural /-s/: strings such as SS_ favor a following plural marker, while combinations such as $\mathrm{S} \varnothing$ _ favor a missing /-s/ (Scherre, 1998a, 1998b, 1998c, 2001; Scherre \& Naro, 1991, 1992, 1998). In Misiones Portuguese rates of depleted plural marking are so high as to be nearly categorical, as shown in Table 1. Of the fortyeight speakers who provided representative data, nineteen did not produce even a single instance of a fully-agreeing plural NP, and probing for possible linear parallel effects is not feasible. Given the extremely high rate of depleted plural marking a logistic regression analysis (in GOLDVARB) is not useful since most of the results are knockouts (no variation). Preceding string elements provide no robust linear priming effects. Although the data in Table 1 seem to suggest that SS__ may favor plural marking on the immediately following element, this difference is not statistically significant; a GOLDVARB run on all variable factor groups did not choose any as significantly affecting depleted plural marking in Misiones Portuguese. Speaker gender, age group, schooling in Spanish, or community of residence also do not significantly affect the rates of plural marking in spontaneous speech. These facts set Misiones Portuguese apart from all reported studies of vernacular Brazilian Portuguese, which typically include at least some sociolinguistic variation as well as linguistically-conditioned variability within a given speech community. Although nearly all Misiones Portuguese speakers listen to Brazilian radio and television-programs in which plural /-s/ is marked on all NP elements-the almost total elimination of multiple plural agreement in local vernacular Portuguese leaves open the possibility of a restructured system of single-marking of nominal plural.

\section{Realization of First-Person Plural Verb Forms in $-\mathrm{MO}(\mathrm{S})$}

The omission of /-s/ in the first-person plural verbal suffix /-mos/ is widely acknowledged for vernacular Brazilian Portuguese, but rates of deletion are rarely reported in variationist studies, which typically lump together realizations of $-m o s$ and $-m o$ as opposed to non-agreeing third-person singular forms (e.g., Lucchesi, 2006:101-102; Mattos, 2013:71-72; Naro et al., 1999; Rubio, 2007; Rubio \& Gonçalves, 2010; Scherre \& Naro, 1998). In one of the few available quantitative studies, for Rio Grande do Sul state (bordering on Misiones province, Argentina) Zilles et al. (2005) found an average rate of elimination of /-s/ in the first-person plural suffix /-mos/ of $34 \%$, with rates as high as $78 \%$ for periphrastic future forms in vamo[s] + infinitive 'we're going to ...' Speakers with only primary education (in Portuguese) deleted /-s/ at the average rate of $47 \%$, compared with a deletion rate of $20 \%$ for speakers with secondary education. There was also a strong correlation between deletion of /-s/ and the realization of first-conjugation 1PL forms in -emo instead of canonical -amo[s].

The Misiones Portuguese corpus yielded 771 tokens of first-person plural verb forms, of which 768 (99.6\%) lacked the final /s/ of the canonical suffix /-mos/ (the three tokens of -mos with final /-s/ realized phonetically were all produced by the same speaker). Furthermore all first-person plural verbs of the first (-ar) conjugation were realized with the suffix -emo rather than the canonical amo(s). Compared to data from Brazil, first-person plural verbal morphology in Misiones Portuguese is almost categorically non-canonical.

\section{Invariant Forms for First-Person Plural Verbs}

Vernacular Brazilian Portuguese is characterized by the frequent use of invariant verb forms (derived from the third-person singular) instead of first- and third-person plural forms (e.g., Azevedo, 1989:865; Guy, 1981:234f.; Lucchesi, 1998:85f.). The replacement of first-person plural verb forms by invariant third-person singular forms predominates in the imperfect tense (e.g., Naro et al., 1999:203; Rodrigues, 2004:123-124; Seara, 2000:183-184; Zilles et al., 2005:204), possibly due to the tendency to avoid verbal forms with antepenultimate stress. Naro et al. (1999:204) did not include rates of replacement of first-person plural forms by thirdperson singular for imperfect verbs, given the extremely high rates. Bortoni-Ricardo (1985:213) reported average rate of $44 \%$ invariant forms for a rural Brazilian dialect; Rodrigues (1992) found some $47 \%$ of omission of the first-person plural marking in a poor favela dialect. For Rio Grande do Sul Zilles et al. (2005:206) obtained a $13 \%$ rate of replacement of first-person plural forms by third-person singular. Rubio (2007:383) found only $10 \%$ replacement ( $9 \%$ for females and $14 \%$ for males), although no division by verb tense is included. Rubio and Gonçalves (2010:171-173) found a $20.5 \%$ replacement rate, rising to $40 \%$ for imperfect verbs (whose 1PL forms bear antepenultimate stress).

The vernacular Misiones Portuguese corpus yielded 81 tokens of first-person plural verb forms in the imperfect tense, which in canonical Portuguese would end in -mos with antepenultimate stress (trabalhávamos 'e.g., trabalávamos 'we used to work,' iamos 'we used to go' $^{\prime}$ ), of which $80(98.8 \%)$ were realized as third-person singular forms (trabaiava, ia, etc.). Once more these data reflect the nearly categorical status of these noncanonical variants in Misiones Portuguese as opposed 
to the greater variability found in Brazilian speech communities.

\section{A Speeded-Translation Experiment}

Given the putative differences between Misiones Spanish and Misiones Portuguese (nominal plural marking, first-person plural verbal marking) as well as the fact that Misiones Portuguese speakers are in virtual contact (television and radio) with Brazilian varieties with full plural agreement and complete first-person plural verbal marking, a translation experiment was conducted in order to determine the extent to which Misiones bilingual speakers maintain similar underlying systems for both languages, differing only in language-specific implementation procedures. Speeded translation provides the maximum degree of crosslinguistic priming (e.g., Bernolet, Hartsuiker \& Pickering, 2012; Desmet \& Declerq, 2006; Hartsuiker, Pickering \& Veltkamp, 2004; Kantola \& van Gompel, 2011; Schoonbaert, Hartsuiker \& Pickering, 2007). It was hypothesized that upon hearing Spanish multi-word plural noun phrases realized with full agreement in /-s/ participants would be most likely to realize the corresponding Portuguese forms with full plural marking, assuming that the speakers' Portuguese grammars provided for multiple plural agreement. Similarly, when translating into Spanish Portuguese noun phrases with depleted plural marking (including invariant consonant-final head nouns), the robustness of multiple plural marking in bilingual speakers' Spanish would be put to the test. In the same fashion, if the first-person plural verbal suffix in Portuguese is /-mos/ with variably-deleted final /-s/ then priming with Spanish verb forms in -mos is expected to trigger a higher level of realization of final /-s/ in Portuguese. Finally, priming by Spanish first-person plural verbsincluding imperfect forms with antepenultimate stress-should trigger similar forms in Portuguese, rather than invariant $3 \mathrm{~S}$ forms. To the extent that these priming effects can be observed, it can be concluded that Misiones Portuguese has not been grammatically restructured away from its Ibero-Romance roots.

Translating from Portuguese to Spanish also tests for possible convergence between the two languages. If when prompted with a depleted plural in Portuguese a fully-agreeing plural is produced in Spanish, this would argue for separate instantiations of plural marking. The same holds for priming with first-person plural verb forms in -amo and -emo, and for non-agreeing firstperson plural imperfective verb forms.

\subsection{Participants}

A total of fifty participants (ages 18 to 45) were recruited in El Soberbio, Colonia Alicia, and Pozo Azul with the help of teachers from the local E.F.A. schools (Escuela de la Familia Agrícola 'Schools for Farming Families'). All were natives of Pozo Azul, El Soberbio, Colonia Alicia, Colonia Aurora, and surrounding agricultural colonias including El Fisco, Barrerinho, Paraíso, and Puerto Londero. All were raised in households where Portuguese was the principal home language (some also learned German dialects at home); some also acquired Spanish at home while others spoke no Spanish until beginning school. Many had relatives in Brazil but none had lived in Brazil or received any formal instruction in Portuguese. All had completed at least the first year of secondary education in Misiones.

\subsection{Materials}

A total of ninety stimulus utterances were created using various text-to-speech programs with voices in Latin American Spanish and Brazilian Portuguese. Thirty utterances were entirely in Spanish, thirty were entirely in Portuguese, and thirty contained various combinations of Spanish and Portuguese (as part of a separate probe for participants' reactions to "Portuñol" admixtures). Since some of the utterances contained elements from both Spanish and Portuguese it was necessary to "deceive" the text-to-speech programs in order to produce reasonable approximations to Spanish and Portuguese phonotactics within a single utterance. In general it was easier to generate Spanish-like utterances from the Portuguese voices rather than creating Portuguese elements from the Spanish voices. Only female voices were used, and fundamental frequency (F0) range and speech rate were digitally manipulated with PRAAT software to achieve maximum consistency (Boersma and Weenink, 1999-2005). All stimuli utterances were normalized for intensity. Each utterance was followed by a $500 \mathrm{~ms}$. gap and an audible beep. The Spanish stimuli were produced with full sibilant [s] in all coda positions, including in plural-agreeing noun phrases and first-person plural verb forms in -mos. The Portuguese voices exhibited the nearly pan-Brazilian palatalization of / $t$ / and / $/$ / before [i], a trait not as categorical in Misiones Portuguese but recognized by all speakers. The palatal lateral phoneme $/ K /$ found in canonical Brazilian Portuguese was changed to a palatal approximant [j] and word-final / $\mathrm{f} /$ was elided, in conformity with vernacular Misiones Portuguese; thus trabalhar [tra.ba.Káx] 'to work' was rendered as [tra.ba. já]. Multi-word plural noun phrases were divided among fully-agreeing (always with sibilant [s]) and depleted plurals, with /-s/ affixed only to the first element. For consonant-final head nouns both pluralmarked and invariant forms were included (e.g., muiéres muié 'women-woman'). Similarly, firstperson plural verb forms were divided between those 
ending in the full suffix - mos and forms in $-m o$, and first-conjugation forms included both canonical -amo(s) and regional vernacular -emo variants. The stimulus set also included non-agreeing combinations of first-person plural subjects and third-person singular invariant verbs. All of the aforementioned combinations are found in the vernacular Portuguese of Misiones and in rural areas of the neighboring Brazilian states of Rio Grande do Sul and Santa Catarina. The stimuli were randomized and loaded onto a portable computer.

\subsection{Procedure}

Participants were located in a quiet room in one of the aforementioned schools and listened to the stimuli through over-the-ear headphones. Stimuli and responses were recorded on separate channels of a digital recorder. Respondents were told that they would hear some sentences in Spanish and some in Portuguese; they were instructed to rapidly translate from the language of the stimulus into the "other" language upon hearing the beep. Repetition was not permitted and respondents were timed out if a response was not initiated within two seconds following the beep. It was not revealed that some utterances contained nominal mixtures of Spanish and Portuguese (since a collateral facet of the experiment was to determine participants' reactions to various types of code-switches), and in those (quite infrequent) cases where participants responded to a mixed stimulus by asking which language it was in or into which language it should be translated, the responses were not included.

\subsection{Results: nominal plural marking}

The Spanish-language stimuli contained twenty utterances with plural noun phrases in which plural /-s/ was marked at least twice (e.g., on a determiner and the head noun). The overall results for spontaneous translations into Portuguese are given in Table 2; for each group the first figure in parentheses gives the standard deviation across the stimuli in each group and the

Table 2. Plural marking in Spanish-to-Portuguese translation (50 participants)

\begin{tabular}{lcc}
\hline & $\begin{array}{c}\% \text { full plural } \\
\text { marking }\end{array}$ & $\begin{array}{c}\% / \text {-s } / \text { only } \\
\text { on determiner }\end{array}$ \\
\hline 3-element NP (N = 6) & $78.6 \%(7.6)(26.3)$ & $11.5 \%$ \\
2-element NP (N = 8) & $74.8 \%(13.4)(26.4)$ & $25.2 \%$ \\
consonant-final NP (N =6) & $64.4 \%(9.9)(31.7)$ & $35.6 \%$ \\
ALL plural NPs (N = 20) & $72.7 \%$ & $27.3 \%$ \\
\hline
\end{tabular}

second figure is the standard deviation across participants for all the stimuli in that group. For the threeelement DPs, $9.9 \%$ of the Portuguese translations marked /s / on the determiner plus one other element; in all but one instance this involved the determiner plus the immediately following head noun, e.g. meus primeiros ano 'my first year[s],' as novelas brasileira 'the Brazilian soap opera[s].' This follows the general priming patterns observed for plural marking in Brazilian Portuguese. ${ }^{5}$

The high rate of full plural agreement in Portuguese when primed with fully-agreeing Spanish plural NPs can be taken as evidence that multiple plural marking is fully active in vernacular Misiones Portuguese, while the relatively large standard deviations underscore the considerable variation in the realization of nominal plural, among individual speakers and with respect to specific stimuli. Despite this variation there were no significant differences in the rate of plural marking depending on the type of noun phrase; a repeated-measures ANOVA performed on the arcsinetransformed proportions of full plural marking gives $F(2,147)=1.35, p=.26 .^{6}$ Since all of the participants form part of the same extended speech community (and many interact with one another on a daily basis), the data suggest that the considerable variation in the rate of Portuguese plural marking when primed with Spanish fully-agreeing plural NPs cannot be directly tied to the generally high rate of depleted plurals in spontaneously produced Portuguese but rather represents individual preferences as to the superficial realization of a morphologically complete number agreement system.

The speeded-translation task also provided opportunities to determine whether vernacular Portuguese plural marking carries over to the Spanish of bilingual Misioneros. The Portuguese-language stimuli contained fully-agreeing plural NPs, with both vowel-final and consonant-final head nouns. There were also stimuli with depleted plural-marked NPs (plural /-s/ only on the first element), containing both vowel-final and consonant-final invariant head nouns. The results of translation into Spanish are given in Table 3.

A series of McNemar's chi-square tests reveals no significant differences on rate of incomplete plural marking in Spanish across the categories, while the overall rate of apparently depleted plural marking in Spanish is very small. This is particularly evident in the case of consonant-final head nouns such as animal 'animal,' mujer 'woman,' lugar 'place,' profesor 'teacher,' ciudad 'city,' etc., whose plural forms receive the allomorph /-es/. Even if the final /s/ is elided due to the extreme phonetic reduction of coda /s/ found in Misiones Spanish, the presence of the /e/ suffices to unambiguously signal plural. Many of the potentially 
Table 3. Rate of marking plural only on first element of plural noun phrases, Portuguese-to-Spanish translation (standard deviations in parentheses).

\begin{tabular}{lr}
\hline & $\%$ depleted plural \\
\hline all plural NPs with full agreement $(\mathrm{N}=9)$ & $5.1 \%(3.9 \%)$ \\
all plural NPs with depleted pluralization $(\mathrm{N}=11)$ & $4.8 \%(3.0 \%)$ \\
fully agreeing plural NPs, vowel-final head noun $(\mathrm{N}=5)$ & $5.8 \%(3.6 \%)$ \\
depleted plural NPs; vowel-final head noun $(\mathrm{N}=7)$ & $5.3 \%(3.5 \%)$ \\
fully agreeing plural NPs; consonant-final head noun $(\mathrm{N}=4)$ & $2.8 \%(1.9 \%)$ \\
depleted plural NPs; consonant-final head noun $(\mathrm{N}=4)$ & $3.9 \%(2.1 \%)$ \\
all plural NPs with vowel-final head noun $(\mathrm{N}=12)$ & $5.6 \%(3.3 \%)$ \\
all plural NPs with consonant-final head noun $(\mathrm{N}=8)$ & $3.3 \%(3.1 \%)$ \\
\hline
\end{tabular}

depleted Spanish plurals with vowel-final head nouns are probably due to general coda /s/-reduction rather than to a consistent process of partial plural marking. The fact that depleted Portuguese plural NPs do not prime incomplete pluralization in Spanish any more than fully-agreeing Portuguese plural NPs provides evidence that the vernacular Portuguese phenomenon of partial or depleted plural marking is kept separate and distinct from Spanish multiple plural agreement in Misiones bilinguals. Despite intense contact between Portuguese and Spanish, the fact that all participants are L1 speakers of Portuguese, and the absence of metalinguistic commentary or correction of either Portuguese or Spanish, two fundamentally different systems continue to co-exist: an active variable rule of plural-marking in Portuguese, and effectively categorical plural-marking in Spanish (undermined only by the general process of coda /s/-weakening).

\subsection{Results: first-person plural verb endings in -mo(s)}

The Spanish-language stimuli contained eight utterances with first-person plural verbs in -mos, all with clearly sibilant final [s] as per the text-to-speech voices. All the verbs were either in the present indicative or preterite (whose first-person plural forms are identical to those of the present tense). Participants translated these forms into Portuguese with $61.5 \%-m o s$ and $38.5 \%$-mo (S. D. $7.0 \%$ across stimuli and $34 \%$ across participants). As with depleted plural marking, realization of first-person plural verb endings is highly variable among participants in the same speech community. A Pearson's correlation between depleted plural marking and realization of firstperson plural verbs with -mo yields a correlation coefficient of $.74(p<.0001)$, revealing a pattern of behavior that divides speakers according to the degree of suppression of morphological /-s / in both plural NPs and first-person plural verbs.

The Portuguese-language stimuli contained five tokens of first-person plural verbs in - mos and six tokens of first-person plural verbs in -mo. Participants translated as Spanish -mo (lacking the final /s/ of /-mos/) $16.2 \%$ of the Portuguese forms in -mos and $14.1 \%$ of the Portuguese forms in $-m o$; the difference is not statistically significant. Since there was no priming effect of Portuguese forms in -mo, as with putatively depleted plurals in Spanish the lack of final [s] in the Spanish verbal suffix - mos is probably a manifestation of general coda weakening of Misiones Spanish /-s/.

\subsection{Results: -emo instead of-amo(s)}

Vernacular Misiones Portuguese shares with the rural regions of the neighboring Brazilian states the tendency to realize the first-person plural of first-conjugation (-ar) verbs as -emo rather than the canonical -amo(s). The Spanish-language stimuli contained six tokens of firstperson plural first-conjugation verbs ending in -amos. Participants translated $72.9 \%$ of these tokens as Portuguese -emo(s) (SD 14.7\%), confirming both the vitality and the variability of this process in Misiones Portuguese. The Portuguese-language stimuli contained six tokens of first-conjugation first-person plural forms in -emo(s); there was only one instance of a Spanish translation in -emo(s), which points to the existence of an exclusively Portuguese allomorphy. ${ }^{7}$

\subsection{Results: invariant verbs for first-person plural}

The eight stimuli with first-person plural present-tense verb forms yielded a total of 400 translation responses (fifty participants). Of these responses only three were produced in the invariant third-person singular form characteristic of some vernacular varieties of Brazilian Portuguese. The Spanish-language stimuli also contained two utterances with first-person plural verbs in the imperfect tense (Spanish suffixes -ábamos and -íamos). Participants translated $56.3 \%$ of these verbs with Portuguese invariant third-person singular forms (with and without the accompanying Portuguese subject pronoun nós), which is indicative of a robust quasi-lexicalization 
of antepenultimate-stressed first-person plural verb forms with invariant singular realization. This phenomenon separates vernacular Misiones Portuguese from the surrounding Spanish varieties, in which use of invariant third-person singular verb forms for firstperson plural reference is found only in the most rudimentary Portuguese-influenced interlanguage (and only in a handful of imperfect forms, most notably from ir 'to go' and tener 'to have'). In the translation task the Portuguese-language stimuli contained eight instances of first-person plural verb forms (four in -mos and four in $-m o$ ), and only one instance was translated into Spanish with an invariant third-person singular form. Similarly the Portuguese-language stimuli contained three utterances in which the first-person plural pronoun nós was accompanied by an invariant third-person singular verb form (both present tense and imperfect tense). Given this priming participants translated 34.7\% of the utterances with Spanish invariant third-person singular verb forms (28\% for present-tense and $38.1 \%$ for imperfect). As an illustration of the variability of the mismatch between first-person subject pronouns and third-person verbs, eight of the fifty participants translated some tokens of Spanish -mos by a third-person singular form in Portuguese, seven translated a few tokens of Portuguese nós + third-person singular verb by a Spanish third-person singular verb, and twenty-three produced exemplars of both Spanish-to-Portuguese and Portuguese-to-Spanish mismatches. This diversity of response patterns-together with the fact that twelve participants from the same speech communities produced no non-agreeing first-person plural verbs even with priming-confirms the variable rather than categorical status of this phenomenon. At the same time the tenacity of non-agreeing verb forms is further demonstrated, as is the fact that Portuguese-Spanish bilinguals in Misiones maintain distinct agreement systems for each language.

\subsection{Results: mixed Portuguese-Spanish stimuli utterances}

The all-Spanish and all-Portuguese stimuli analyzed in the preceding sections provoked almost no grammatically mixed translations and only occasional lexical slippage (e.g., using Spanish embarazada instead of Portuguese grávida 'pregnant' or Portuguese morar instead of Spanish vivir 'to reside'). Since the notion of "Portuñol" has frequently been construed as referring to the mixing of Spanish and Portuguese elements within the same utterance-including the possibility of intra-sentential codeswitching - the stimuli presented for translation included thirty utterances containing both Spanish and Portuguese elements. Of the stimuli ten utterances began in Spanish and ended in Portuguese, ten began in Portuguese and ended in Spanish. These typify alternational codeswitching (e.g., Muysken, 2000:96), which while common in many bilingual speech communities is nearly non-existent in Misiones. It was hypothesized that if Misiones "Portuñol" was a truly mixed variety, then stimuli containing both Spanish and Portuguese elements would elicit a substantial proportion of mixed translations. On the other hand if Spanish and Portuguese were implicitly acknowledged as separate languages, then participants would be expected to strive for translations couched in a single language, perhaps primed by the beginning or ending segments of the stimuli.

Table 4 gives the results from the translation of nominally mixed Portuguese-Spanish stimuli utterances.

Despite mixed stimuli, participants produced very few mixed translations and no monotonic responses (beginning in one language and continuing in the other). The directionality of the language mixing in the stimuli utterances was not significant; there was a general tendency to translate mixed utterances into Spanish, perhaps because the participants were aware of the researcher's interest in the local variety of Portuguese. The combination of Spanish interrogative + Portuguese predicate and Spanish auxiliary/modal verb + Portuguese infinitive yielded very high rates of translation as all-Spanish, reflecting generally observed unfavorable environments for intra-sentential codeswitching. Overall, the results for the translation of mixed-language stimuli suggest that Misiones Portuguese is implicitly regarded as an unmixed language by its speakers, "Portuñol" stereotypes notwithstanding.

Table 4. Results of translation task: mixed Portuguese-Spanish stimulus utterances

\begin{tabular}{lccc}
\hline & $\%>>$ Spanish & $\%>>$ Portuguese & $\%>$ mixed \\
\hline Spanish >> Portuguese $\{$ all\} & $70.7 \%$ & $26.8 \%$ & $2.5 \%$ \\
Sp. >> Ptg. $\{$ clause + clause & $58.0 \%$ & $40.0 \%$ & $2.0 \%$ \\
Sp. >> Ptg. \{aux + infinitive\} & $84.3 \%$ & $10.1 \%$ & $5.6 \%$ \\
Sp. >> Ptg. \{interrog. + clause\} & $92.3 \%$ & $6.8 \%$ & $1.0 \%$ \\
Portuguese >> Spanish \{all\} & $67.5 \%$ & $28.3 \%$ & $4.2 \%$ \\
\hline
\end{tabular}




\section{Modeling Misiones Vernacular Portuguese: A Principal Components Analysis}

The linguistic profile of Misiones Portuguese speakers is further elucidated through a principal components analysis of the results of the speeded translation task. This is a technique for studying complex data sets with many variables, by reducing the total number of dimensions. Unlike standard regression models, in which the effect of each variable is calculated individually, PCA creates new categories (the principal components), each composed of some linear combination of all of the input variables. The principal components are calculated in descending order of the amount of total variance in the data set accounted for. The first PC captures the maximum variance in the data. The second PC represents the remaining variance and is uncorrelated with the first PC. Additional principal components successively account for any remaining variance. The total number of principal components is equal to the number of variables with each PC accounting for less of the total variance than the preceding ones. In most practical applications, the first two or three PCs account for most of the variance in the data and represent an effective dimension reduction.

Typically there are correlations among the input variables resulting in redundancy. By successively creating models with different combinations of input variables, the model whose first few principal components account for the greatest amount of variance emerges as the best characterization of the variation in the entire data set.

For the Misiones translation task, a PCA model was fitted in $\mathrm{R}$, using the following variables, each of which contained one value (an arcsine-transformed proportion of the application of the variable) for each of the fifty participants: rate of full plural in Spanishto-Portuguese translation of NPs with (1) vowel-final head noun and with (2) consonant-final head noun; translation into Spanish of (3) full plural-marked and depleted plural-marked Portuguese NPs: (4) voweland (5) consonant-final head nouns; (6) realization of Portuguese first-person plural verbs in -mo rather than -mos; (7) realization of Portuguese first conjugation (-ar) first-person verb forms in -emo instead of -amo(s); (8) translation into Spanish of Portuguese non-agreeing third-person singular present-tense verb forms in place of first-person plural (nós trabaia instead of nós trabalhamos 'we work'); (9) translation into Portuguese of Spanish first-person plural imperfective verb forms with antepenultimate stress ([nosotros] teníamos $>$ nós tínahmos / nós tinha 'we used to have'). Figure 1 shows the results for the first two principal components when all variables are included.

Since each principal component includes the effects of more than one variable, the vectors in Figure 1

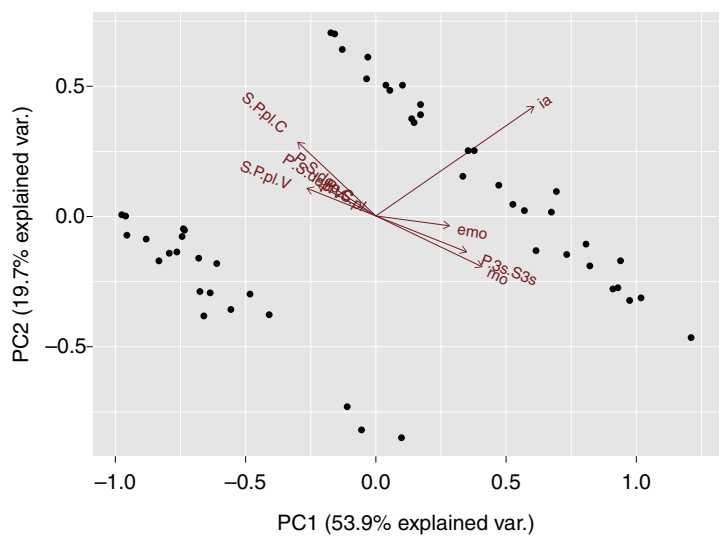

Figure 1. Results of a preliminary principal components analysis, Misiones Portuguese

graphically depict the relative contribution of each input variable on the composition of the principal components. The length of a vector indicates relative importance as a contributing factor to a particular component, while the angle with respect to the horizontal (first PC) and vertical (second PC) axes reflects individual interactions among the variables and the extent to which individual variables contribute to each PC. Thus a completely horizontal vector would be confined to the first PC; a vertical vector would be exclusive to the second PC, while a $45^{\circ}$ vector would contribute equally to each PC. Vectors that point in opposite directions indicate negative correlations, while orthogonal vectors (emerging at right angles) are an indication of independence (no correlation) of the respective variables. The dots represent individual participants, situated with respect to the variation expressed by the first two principal components. The participants are distributed into two clusters, roughly corresponding to the use of canonical vs. non-canonical variants of the input variables.

In Figure 1 it is not surprising that the canonical translation variants (full plural marking, full verbsubject agreement) correlate closely (grouped together in the upper left quadrant) while exhibiting strong negative correlations with the non-canonical variants (Portuguese plurals in -mo, -emo, non-agreeing verb forms in Spanish (grouped in the lower right quadrant). The realization in Portuguese of (invariant or agreeing) first-person plural imperfective forms is orthogonal to the other variables (upper right quadrant), in effect independent of the remaining factors, as shown in Figure 1.

The closely correlated variables indicate that this model is quite redundant and therefore not maximally efficient; the first two PCs account for $73.6 \%$ of the total variance $(53.9 \%$ and $19.7 \%$, respectively). While not a useless dimension reduction, this unrefined model leaves approximately one quarter of the variation 


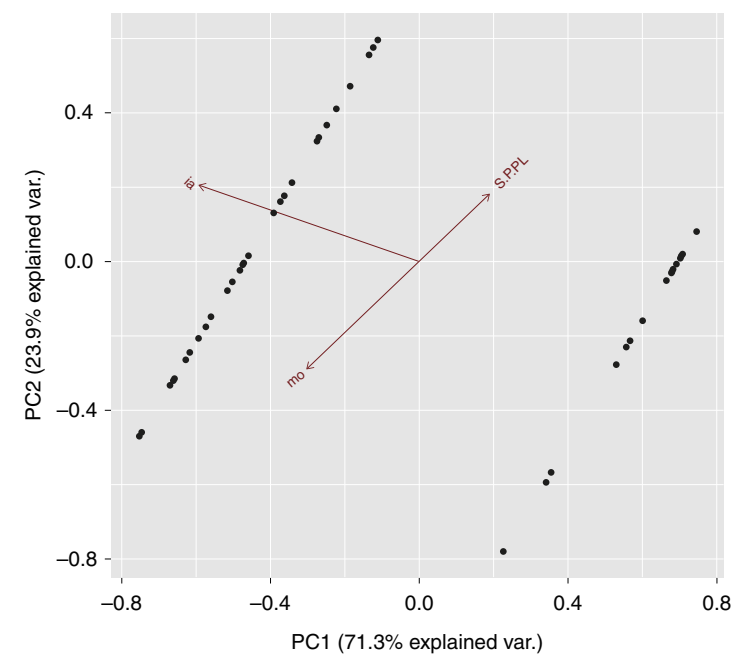

Figure 2. A redundancy-free PCA, Misiones Portuguese

unaccounted for in the first two principal components. The most efficient model is based only on the combined rate of Spanish-to-Portuguese full plural marking of all plural NPs, realization of Portuguese first-person plural verbs in $-m o$, and translation of Spanish first-person plural imperfective verbs as invariant third-person singular in Portuguese. In this model the first two PCs account for $95.2 \%$ of the total variance $(71.3 \%$ and $23.9 \%$, respectively), and split the participants into two even more neatly delimited groups, as shown in Figure 2 . This is a significant improvement over the model with redundancies, and demonstrates that apparently amorphous variation among several variables and many participants can be accounted for by focusing on only a small subset of the variables. The fact that the data points for individual participants form two parallel lines reflect differing individual rates for each variable, while maintaining the overall relationships among the variables.

From this analysis it can be seen that full plural marking of Portuguese NPs (in effect "standard" Portuguese) is inversely correlated with realization of first-person plural verb forms in $-m o$ instead of canonical -mos (i.e. local vernacular Portuguese), confirming the previously reported correlation coefficient. Non-agreement in first-person plural imperfective verb forms splits the participants bi-modally, essentially independently of the other two variables.

Figure 3 plots the same results, differentiated by community. It can be seen that nearly all participants from Colonia Alicia and Pozo Azul tend towards noncanonical variants for all three variables, even when primed with canonical Spanish equivalents. Only in El Soberbio is there a greater proportion of canonical variant production. The same basic pattern holds for the remaining variables.

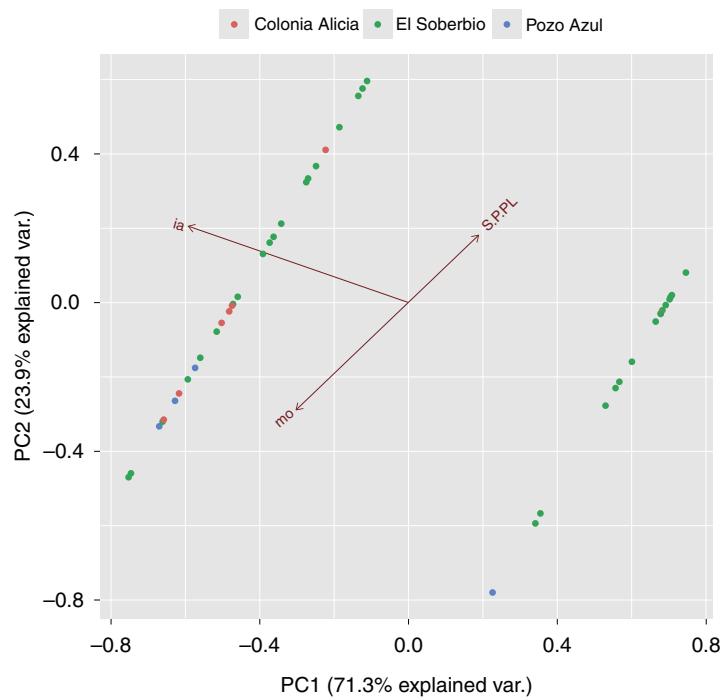

Figure 3. Distribution by speech community/region, Misiones Portuguese

This distribution may reflect the fact that Portuguese is a community-wide language in the small urban environment of El Soberbio as well as in surrounding rural colonias, and there is access to a potentially greater range of variation in spoken Portuguese. Given the relatively small sample size, a full elucidation awaits further research.

\section{General Discussion}

As stated at the outset, the purpose of the present study was to determine if Portuguese and Spanish are undergoing morphosyntactic convergence in the sociolinguistically permissive environment of rural Misiones province in Argentina. The data reported in the preceding sections reveal the highly non-canonical nature of Misiones Portuguese, with respect to the key variables associated with first-person plural verb marking (presence or absence of $-s$ in the desinence - mos, realization of first-conjugation verbs in -emo(s) instead of amo(s), invariant realization of imperfective forms) and plural marking and agreement in NPs. In the aggregate, Misiones Portuguese speakers exhibit much highernearly categorical - rates of non-canonical variants than has been reported for contemporary Brazilian sociolects, and they show little evidence of the emulation of standard varieties heard on Brazilian television and radio. On the other hand, intense and spontaneous bilingual contact with Spanish has resulted in little morphosyntactic convergence in the representative variables studied: plural marking in noun phrases and first-person plural verbal morphology. Misiones Spanish as spoken by Portuguese-Spanish bilinguals is much closer to national and international patterns than Misiones Portuguese, and shows no consistent signs of 
incorporating the non-standard morphosyntactic patterns that predominate in vernacular Misiones Portuguese. Nor is Misiones Portuguese emulating Spanish patterns which if adopted would bring local Portuguese more in line with canonical Brazilian patterns. Since most of the morphosyntactic patterns described for Misiones Portuguese are variable rather than categorical-as confirmed by priming from Spanishconvergence would not necessarily involve fundamental restructuring, but only quantitative alteration in the application of variable rules. When primed by homologous Spanish structures, most vernacular Misiones Portuguese speakers give evidence of a fully intact system of plural marking in NPs with no essential restructuring. The final /-s/ in first-person plural verbs is also restored at a much higher rate than in casual speech, again suggesting that elision of /-s/ in -mos has not resulted in restructuring. Similarly, many firstconjugation verbs whose first-person plural forms are typically produce with the-emo(s) endings "revert" to amo(s) when primed with Spanish cognates, ${ }^{8}$ and nonagreeing first-person plural forms are confined to only a few possibly lexicalized exemplars when primed by fully agreeing Spanish verbs. If convergence between Portuguese and Spanish were widespread in Misiones, it would be expected that when cued by Spanish, Misiones Portuguese speakers might increase the frequency of first-person plural verb endings in -mos instead of $m o$ and would avoid -emo(s) forms for first-conjugation (-ar) verbs cognate with Spanish. Use of third-person singular imperfective verb forms instead of first-person plural should also be on the wane. Convergence with Spanish should result in a high rate of /s/-marking on all elements of plural noun phrases in Misiones Portuguese, and the avoidance of invariant consonantfinal plural forms. Conversely, some of the variable processes described for Misiones Portuguese might be expected to creep into the Spanish of Portuguesedominant bilinguals, e.g. partially plural-marked NPs, first-person plural endings in -emo(s) for firstconjugation verbs, and non-agreeing first-person plural verbs. That none of this happens spontaneously —and only sparsely with intense priming-indicates that bilingual contact is a necessary but not sufficient condition for convergence. On the other hand the variant -emo instead of -amo(s) has been lexicalized for many speakers, even when primed with cognate Spanish verbs in -amos. The same holds for invariant first-person plural imperfective verbs, especially ia 'go' and tinha 'have.'

Although Portuguese is the first and often dominant language of the individuals who provided data for this study, and who typify the entire rural region of eastern Misiones, the vernacular Spanish spoken by Misiones Portuguese speakers shows few signs of convergence with Portuguese, even when primed by a translation task. Invariant plural nouns and invariant verb forms are vanishingly rare and first-person plural verb forms retain final /-s/, subject to the variable aspiration/ deletion characteristic of Misiones Spanish. Firstconjugation (-ar) verbs take -amos rather than -emo(s) in first-person plural forms. Translations of monolingual utterances yield monolingual equivalents, and translation of mixed utterances also produced monolingual results, all of which is consistent with the interpretation of Misiones Portuguese as an essentially un-mixed language.

\subsection{Misiones Portuguese is different from Uruguayan Fronterizo}

Despite apparent similarities (vernacular Portuguese spoken natively near the Brazilian border in a Spanishspeaking country), the differences between Misiones Portuguese and northern Uruguayan Portuguese varieties are noteworthy. The vernacular Portuguese varieties of northern Uruguay show evidence of partial but stable morphosyntactic convergence between Portuguese and Spanish, in a fashion not inconsistent with the notion of a Fronterizo language that combines essential features of Portuguese and Spanish. The Uruguayan situation is unlike Misiones Portuguese, which shows little convergence with Spanish. Comparative studies of Portuguese-Spanish linguistic contacts in various other communities along the Brazilian border (Lipski 2011a, 2011b, 2015) suggest that Uruguayan Fronterizo arose not from simple bilingual contact but rather from the gradual nativization of an originally L2 interlanguage - in this case vernacular Portuguese speakers acquiring Spanish (Lipski 2008a, 2009a). Issues of identity may also have played a role in consolidating hybrid combinations even in the presence of canonical Spanish and Portuguese varieties. The Uruguayan artist Chito de Mello has used the term la bagacera, literally meaning the detritus left from grinding sugar cane, to refer to the working-class Portuguese/Portunhol speakers of northern Uruguay. This term is used defiantly, an assertion of identity that rejects the rompeidioma ('language-breaker') designation reflective of the de facto correlation between socio-economic class and language usage. The data from Misiones, Argentina, where the use of vernacular Portuguese is more broadly accepted, and where the use of Portuguese rather than Spanish is not broadly regarded as an identity marker, confirm that unrestricted bilingual contact alone is not sufficient to yield stable morphosyntactic convergence between Portuguese and Spanish. Unlike in northern Uruguay, the linguistic ecology of Misiones has not resulted in linguistic hybridity as a manifestation of cultural identity; even in the absence of sociolinguistic 
pressures to conform to canonical patterns, Portuguese and Spanish morphosyntactic configurations have not converged.

\section{Conclusions}

The influence of Spanish on Misiones Portuguese is undeniable, especially as regards lexical borrowings and occasional calques. At the same time a comparison of three fundamental grammatical features of vernacular Misiones Portuguese with locally spoken Spanish, as observed in spontaneous speech and as produced under elicited translation, confirms the existence of distinct systems of nominal plural marking and firstperson plural verbal inflections. Popular stereotypes postulate the inevitable mixing and eventual convergence of Portuguese and Spanish left adrift in a contact situation, but in Misiones even the intense contact and near-absence of formal linguistic instruction and prescriptivist pressure have not turned Portuguese or Spanish into "Portuñol."

\section{Acknowledgments}

I gratefully acknowledge the assistance of the following individuals, without whose help this research would not have been possible: Liliam Prytz Nilsson (Ministry of Education, Posadas), Viviana Eich, Liliana Daviña, and Ivene Carissini da Maia (Universidad Nacional de Misiones, Posadas), Sergio Chajkowski and Rosendo Fuchs (Panambí), Hugo Cámara Robles (Comandante Andresito), Sandra Grabe (Puerto Iguazú), Nélida Aguerre (Alba Posse), Norma Ramírez, Justino Steinhaus, and Ricardo Leiva (El Soberbio), Darío Miranda and Manglio Vargas (Colonia Alicia), Elsa Rodríguez de Olivera (25 de Mayo), Daniel Ziemann and Carlos Knoll (Santa Rita), Fátima Zaragoza and Juan Carlos Morínigo (Bernardo de Irigoyen), Isabelino Fonseca (San Antonio), Roberto Pinto (San Javier), Marcelo Ragotín, Cristina Barchuk, and Luis Alberto Vogeli (Pozo Azul). Thanks are also due to the dozens of Misioneros who have graciously welcomed me into their homes and lives and have shared their languages with me.

\section{Notes}

1 As pointed out by an anonymous reviewer, Spanish speakers who visit Brazil usually encounter no obstacles to making themselves understood using Spanish. In the aforementioned border communities Spanish speakers' choice to speak Portuguese to Brazilians is often motivated by commercial exchanges (e.g. with Brazilian clients), the predominance of Brazilian radio and television programs, or simply because historically the city on the Brazilian side of the border offered more services.
2 As noted, for example, by Bortoni-Ricardo (1981: 93) and Azevedo (1989: 870), mere contact with a prestige dialect is not sufficient for speakers of non-canonical vernacular varieties to gravitate towards canonical forms; formal school instruction is also implicated in the emulation of prestige varieties.

3 A selection of newspaper articles that mention "portuñol" in a generally non-judgmental fashion includes: www.misionesonline.net/noticias/21/06/2005/misionesplanto-bandera-en-territorio-del-portunolwww.argentinaturismo.com.ar/santarita/

www.territoriodigital.com/nota.aspx?c=3590085293363317 www.misionesonline.net/noticias/21/06/2005/misionesplanto-bandera-en-territorio-del-portunol http: / /aulaintercultural.org/printbrev.php3?id_breve=321 www.misionesonline.net/noticias/04/03/2005/rovira-anun cio-que-se-extendera-la-escuela-bilingue-a-toda-la-fronteraoriental-donde-la-provincia-realiza-inversiones-historicas www.infobae.com/notas/nota.php?Idx=172450\&idx Seccion $=0$

http://archivo.univision.com/content/content.jhtml? cid $=569893$

www.lanacion.com.ar/684855-la-argentina-y-brasilse-unen-en-una-frontera-educativa www.pagina12.com.ar/diario/sociedad/3-48074-200503-05.html

http:/ / fmamerica.com.ar/index.php?option=com content\&view=article\&id=10263:-el-portunol-nacio-enla-triple-frontera-y-esta-de-moda\&catid=79:curiosidades\& Itemid $=113$

http://www.elsoberbioportaldelmocona.com/?modulo= secciones\&id $=8$

http://www.visitemosmisiones.com/bernardo_de_irigoyen. $\mathrm{html}$

4 Monetary units such as dólar 'dollar,' guaraní (the Paraguay currency) and bolivar (the Venezuelan currency) can often be heard in the singular when accompanied by numbers, and in highly restructured vernacular Caribbean Spanish (e.g. in the Dominican Republic) invariant consonant-final plurals also occur.

5 There was one instance where / s / was marked only on the second element: mucha outras coisa 'many other things.' The fact that Spanish muchas 'many (f. pl.) was not translated into Portuguese (muita[s]) suggests momentary confusion on the part of the participant (who routinely produced 2- and 3-elements DPs with /s/ only on the determiner but no other atypical combinations.

6 By considering only the average rate of plural marking for each stimulus utterance, consonant-final head nouns exhibit significantly different rates of marking plural only on the determiner than (2- and 3-element) NPs with vowel-final head nouns as revealed by a Welch's t-test performed on the arcsine-transformed proportion of full plural marking: Welch $t(15.44)=-3.20, p=.006$. Given the small number of stimuli in each group and the large standard deviation across stimuli this result is probably not indicative of systematic differences across the entire language.

7 Many vernacular Misiones Portuguese speakers employ the third-person reflexive pronoun se instead of the 
first-person plural reflexive nos in reflexive verb constructions, e.g., nós se [nos] casemo(s) 'we got married.' This usage is not commonly found in monolingual rural Misiones Spanish. The Portuguese-language stimuli contained two first-person plural reflexive verbs with $s e ; 13.5 \%$ of the Spanish translations involving a reflexive verb form maintained se instead of canonical Spanish nos. Given the scarcity of this combination in spontaneous Misiones Spanish, this result is most likely the direct effect of priming from the Portuguese stimuli.

8 Both the data from the corpus and the results of the translation task suggest that for some speakers, certain forms in -emo for first-conjugation verbs may be lexicalized.

\section{References}

Amable, Hugo. 1975. Las figuras del habla misionera. Santa Fe: Librería y Editorial Colmegna.

Amorim, Jane da Silva. 2007. El fenómeno portuñol practicado por comerciantes brasileños en el área de frontera Brasil-Venezuela: Un estudio macro sociolingüístico. Norte Científico: periódico anual técnico-científico do CEFET-RR 2(1). 169-184.

Azevedo, Milton. 1989. Vernacular features in educated speech in Brazilian Portuguese. Hispania 724). 862-872.

Behares, Luis Ernesto. 2005. Uruguai / Brasil: Contribuição ao estudo da heterogeneidade lingüístico-cultural da fronteira sul. Diálogos Possíveis 2. 29-45.

Bernolet, Sarah, Robert Hartsuiker \& Martin Pickering. 2012. Effects of phonological feedback on the selection of syntax: Evidence from between-language syntactic priming. Bilingualism: Language and Cognition 15(3). 503-516.

Bortoni-Ricardo, Stella Maris. 1981. A concordância verbal em português: Um estudo de sua significação social. In Hildo Honório do Couto (ed.), Ensaios de lingüística aplicada ao português, 79-95. Brasília: Thesaurus.

Bortoni-Ricardo, Stella Maris. 1985. The urbanization of rural dialect speakers: A sociolinguistic study in Brazil. Cambridge: Cambridge University Press.

Carrasco, Cantos, Pilar. 1981. Contribución al estudio del habla rural de Baeza (Jaén). Jaén: Instituto de Estudios Giennenses.

Carvalho, Ana Maria. 2003a. Rumo a uma definição do Português Uruguaio. Revista Internacional de Lingüística Iberoamericana 1(2). 125-149.

Carvalho, Ana Maria. 2003b. The sociolinguistic distribution of (lh) in Uruguyan Portuguese: A case of dialect diffusion. In Silvina Montrul and Francisco Ordóñez (eds.), Linguistic theory and language development in Hispanic languages, 30-44. Somerville, MA: Cascadilla Press.

Carvalho, Ana Maria. 2004a. I speak like the guys on TV: Palatalization and the urbanization of Uruguayan Portuguese. Language Variation and Change 16(2). 127-151.

Carvalho, Ana Maria. 2004b. Diagnóstico sociolingüístico de comunidades escolares fronterizas en el norte de Uruguay. In Claudia Brovetto and Javier Geymonat (eds.), Portugués del Uruguay y educación bilingüe, 44-96. Montevideo: Administración Nacional de Educación Pública.

Carvalho, Ana Maria. 2006a. Políticas lingüísticas de séculos passados nos dias de hoje: $\mathrm{O}$ dilema sobre a educação bilíngüe no norte do Uruguai. Language Problems and Language Planning 30(2). 149-171.

Carvalho, Ana Maria. 2006b. Nominal number marking in a variety of Spanish in contact with Portuguese. In Timothy L. Face and Carol A. Klee (eds.), Selected Proceedings of the 8th Hispanic Linguistics Symposium, 154-166. Somerville, MA: Cascadilla Proceedings Project.

Daviña, Liliana Silvia. 2003. Fronteras discursivas en una región plurilingüe: Español y portugués en Misiones. Buenos Aires: Universidad de Buenos Aires MA thesis.

Desmet, Timothy \& Mieke Declercq. 2006. Cross-linguistic priming of syntactic hierarchical configuration information. Journal of Memory and Language 54(4). 610-632.

Douglas, Kendra. 2004. Uruguayan Portuguese in Artigas: Tridimensionality of transitional local varieties in contact with Spanish and Portuguese standards. Madison, WI: University of Wisconsin dissertation.

Elizaincín, Adolfo. 1973. Algunos aspectos de la sociolingüística del dialecto fronterizo. Montevideo: Universidad de la República.

Elizaincín, Adolfo. 1976. The emergence of bilingual dialects on the Brazilian-Uruguayan border. International Journal of the Sociology of Language 9. 123-134.

Elizaincín, Adolfo. 1979. Algunas precisiones sobre los dialectos portugueses en el Uruguay. Montevideo: Universidad de la República.

Elizaincín, Adolfo. 1992. Dialectos en contacto: Español y portugués en España y América. Montevideo: Arca.

Elizaincín, Adolfo \& Luis Behares. 1981. Variabilidad morfosintáctica de los dialectos portugueses del Uruguay. Boletín de Filología (Chile) 31. 401-417.

Elizaincín, Adolfo, Luis Behares \& Graciela Barrios. 1987. Nos falemo brasilero. Montevideo: Editorial Amesur.

Ferreira, Fernanda. 2001. Variation in Ibero-Romance: A study of $/ s /$ reduction in Brazilian Portuguese in comparison with Caribbean Spanish. Albuquerque, NM: University of New Mexico dissertation.

Guy, Gregory. 1981. Linguistic variation in Brazilian Portuguese: aspects of the phonology, syntax, and language history. Philadelphia: University of Pennsylvania dissertation.

Guy, Gregory. 2014. Variation and change in Latin American Spanish and Portuguese. In Patrícia Amaral and Ana Maria Carvalho (eds.), Portuguese-Spanishi interfaces: Diachrony, synchrony, and contact, 443-464. Amsterdam \& Philadelphia: John Benjamins.

Hartsuiker, Robert, Martin Pickering \& Eline Veltkamp. 2004 Is syntax separate or shared between languages? Cross linguistic syntactic priming in Spanish-English bilinguals. Psychological Science 15. 409-414.

Hensey, Fritz. 1972. The sociolinguistics of the BrazilianPortuguese border. La Haya: Mouton.

Hensey, Fritz. 1975. Fronterizo: A case of phonological restructuring. In Jacob Ornstein (ed.), Three essays on linguistic diversity in the Spanish-speaking world, 47-59. Rowley, MA: Newbury House.

Hensey, Fritz. 1982a. Uruguayan fronterizo: A linguistic sampler. Word 33(1). 93-198.

Hensey, Fritz. 1982b. Spanish, Portuguese and Fronteriço: Languages in contact in northern Uruguay. International Journal of the Sociology of Language 34. 9-23. 
Kantola, Leila \& Roger van Gompel. 2011. Between- and within-language priming is the same: Evidence for shared bilingual syntactic representations. Memory and Cognition 39(2). 276-290.

Kaufmann, Göz. 2009. Falar espanhol or hablar portugués: Attitudes and linguistic behavior on the BrazilianUruguayan and Brazilian-Argentinian borders. Romanistisches Jahrbuch 60. 276-317.

Lipski, John. 1985. Linguistic aspects of Spanish-English language switching. Tempe: Arizona State University, Center for Latin American Studies.

Lipski, John. 2006. Too close for comfort? The genesis of "portuñol/portunhol.". In Timothy L. Face and Carol A. Klee (eds.), Selected proceedings of the 8th Hispanic Linguistics Symposium, 1-22. Somerville, MA: Cascadilla Press.

Lipski, John. 2008a. Searching for the origins of Uruguayan Fronterizo dialects: Radical code-mixing as "fluent dysfluency.". Journal of Portuguese Linguistics 8. 5-46.

Lipski, John. 2008b. Afro-Paraguayan Spanish: The negation of non-existence. Journal of Pan-African Studies 2(7). 2-32.

Lipski, John. 2009a. "Fluent dysfluency" as congruent lexicalization: A special case of radical code-mixing. Journal of Language Contact 2. 1-39.

Lipski, John. 2009b. El habla de los afroparaguayos: Un nuevo renglón de la identidad étnica. Lexis 33. 91-124.

Lipski, John. 2010. Depleted plural marking in two AfroHispanic dialects: Separating inheritance from innovation. Language Variation and Change 22. 1-44.

Lipski, John. 2011a. Um caso de contato de fronteira: O sudoeste. In Heliana Mello, Cléo, Altenhofen and Tommaso Raso (eds.), Os contatos linguísticos no Brasil, 349-368. Belo Horizonte: Editora UFMG.

Lipski, John. 2011b. Encontros lingüísticos fronteiriços. Ideação 13(2). 83-100, http:/ /e-revista.unioeste.br/index.php/ ideacao/article/viewArticle/6109.

Lipski, John. 2015. Portuguese/portuñol in Misiones, Argentina: Another Fronterizo?. In Sandro Sessarego and Melvin González (eds.), New perspectives on Hispanic contact linguistics. Frankfurt \& Madrid: Vervuert/Iberoamericana.

Lucchesi, Dante. 1998. A constitução histórica do português brasileiro como um processo bipolarizador: Tendências atuais de mudança nas normas culta e popular. In Sybille Grosse and Klaus Zimmermann (eds.), "Substandard" e mudança no português do Brasil, 73-99. Frankfurt am Main: TFM.

Lucchesi, Dante. 2006. Parâmetros sociolingüísticos do português brasileiro. Revista da ABRALIN 5(1). 83-112.

Maia, Ivene Carissini da. 2004. Intercambios lingüísticos de frontera: incidencia el el hablar de los alumnos del profesorado en portugués de la UNAM. Posadas, Argentina: Universidad Nacional de Misiones MA Thesis.

Marcos Marín, Francisco. 2001. De lenguas y fronteras: El espanglish y el portuñol. Nueva Revista de Política, Cultura y Arte 74 (marzo-abril), 70-79.

Mattos, Shirley Eliany Rocha. 2013. Goiás na primeira pessoa do plural. Brasília: Universidade de Brasília dissertation.

Muysken, Pieter. 2000. Bilingual speech: A typology of code-mixing. Cambridge: Cambridge University Press.

Naro, Anthony, Edair Görski \& Eulália Fernandes. 1999. Change without change. Language Variation and Change 11. 197-211.
Poplack, Shama. 1980. Deletion and disambiguation in Puerto Rican Spanish. Language 56. 371-385.

Poplack, Shama. 1981. The notion of the plural in Puerto Rican Spanish: Competing constraints on (s) deletion. In William Labov (ed.), Locating language in time and space, 55-67. New York: Academic Press.

Rodrigues, Angela C. S.. 1992. Lingua e contexto sociolingüístico, concordância verbal no português popular de São Paulo. In, Publicação do Curso de Pós-Graduação em Lingüística e Língua Portuguesa, no. 2. 153-171. Aranquara: UNESP-Campus de Aranquara.

Rodrigues, Angela C. S.. 2004. Concordância verbal, sociolingüística e história do português brasileiro. Fórum Lingüístico (Florianópolis) 4(1). 111-145.

Rona, José Pedro. 1960. La frontera lingüística entre el portugués y el español en el norte del Uruguay. Veritas 8. 201-219.

Rona, José Pedro. 1969. El dialecto "fronterizo" del norte del Uruguay. Montevideo: Adolfo Linardi.

Rubio, Cássio Florêncio. 2007. Por uma definição da variante estigmatizada na concordância verbal no interior paulista: A atuação da variável gênero/sexo. Estudos Lingüísticos 36(2). 380-388.

Rubio, Cássio Florêncio \& Sebastião Carlos Leite Gonçalves. 2010. Opções metodológicas no estudo de fenômenos variáveis relacionados à primeira pessoa do discurso no plural. Niterói 29. 161-182.

Sanicky, Cristina. 1981. The pronunciation of Spanish in Misiones, Argentina. Davis, California: University of California dissertation.

Scherre, Maria Marta Pereira. 1998a. Sobre a influência de três variáveis relacionadas na concordância nominal em português. In Giselle Machline de Oliveira e Silva and Maria Marta Pereira Scherre (eds.), Padrões sociolingüisticos: Análise de fenômenos variáveis no português falado na cidade de Rio de Janeiro, 85-117. Rio de Janeiro: UFRJ, Departamento de Lingüística e Filologia.

Scherre, Maria Marta Pereira. 1998b. Sobre a influência de variáveis sociais na concordância nominal. In Giselle Machline de Oliveira e Silva and Maria Marta Pereira Scherre (eds.), Padrões sociolingüisticos: Análise de fenômenos variáveis no português falado na cidade de Rio de Janeiro, 239-264. Rio de Janeiro: UFRJ, Departamento de Lingüística e Filologia.

Scherre, Maria Marta Pereira. 1998c. Variação da concordância nominal no português do Brasil: Influência das variáveis posição, classe gramatical e marcas precedentes. In Sybille Grosse and Klaus Zimmermann (ds.), "Substandard" e mudança no português do Brasil, 153-188. Frankfurt am Main: TFM.

Scherre, Maria Marta Pereira. 2001. Phrase-level parallelism effect on noun phrase number agreement. Language Variation and Change 13. 91-107.

Scherre, Maria Marta Pereira \& Anthony Naro. 1991. Marking in discourse: "Birds of a feather.". Language Variation and Change 3. 23-32.

Scherre, Maria Marta Pereira \& Anthony Naro. 1992. The serial effect on internal and external variables. Language Variation and Change 4. 1-13.

Scherre, Maria Marta Pereira \& Anthony Naro. 1998. Sobre a concordância de número no português falado do Brasil. In Giovanni Ruffino (ed.), Atti del XXI congresso internazionales 
di Linguistica e Filologia Romanza, sezione 5: Dialettologia, geolinguistica, sociolinguistica, 509-523. Tübingen: Max Niemeyer.

Schoonbaert, Sofie, Robert Hartsuiker \& Martin Pickering. 2007. The representation of lexical and syntactic information in bilinguals: Evidence from syntactic priming. Journal of Memory E Language 56(2). 153-171.

Seara, Izabel Christine. 2000. A variação do sujeto nós e a gente na fala florianopolitana. Organon 14(28/29). 179-194.

Sturza, Eliana Rosa. 1994. O espanhol do cotidiano e o espanhol da escola: um estudo de caso na fronteira Brasil-Argentina. Santa Maria, Brazil: Universidade Federal de Santa Maria MA thesis. Sturza, Eliana Rosa. 2004. Fronteiras e práticas lingüísticas: Um olhar sobre o portunhol. Revista Internacional de Lingüística Iberoamericana 2. 151-160.
Sturza, Eliana Rosa. 2005. Línguas de fronteira: O desconhecido território das práticas lingüísticas nas fronteiras. Ciência e Cultura 57(2). 47-50, http:/ / cienciaecultura.bvs.br/pdf/cic/v57n2/a21v57n2.pdf.

Sturza, Eliana Rosa \& I. C. Fernandes. 2009. A fronteira como novo espaço de representação do espanhol no Brasil. Revista Signo E Seña 20. 209-227.

Waltermire, Mark. 2006. Social and Linguistic Correlates of Spanish-Portuguese Bilingualism on the Uruguayan-Brazilian Border. Albuquerque, NM: University of New Mexico dissertation.

Zilles, Ana Maria Stahl, Leonardo Zechlinski Maya \& Karine Quadros da Silva. 2005. A concordância verbal com a primeira pessoa do plural em Panambí e Porto Alegre, RS. Organon 14(28/29). 195-219. 